\title{
Response of cottontail rabbit populations to herbicide and fire applications on cross timbers rangeland
}

\author{
R.L. LOCHMILLER, J.F. BOGGS, S.T. MCMURRY, D.M. LESLIE, JR., AND D.M. ENGLE
}

\section{Abstract}

Knowledge of how resident wildlife populations respond to brush management strategies is especially limited for rangelands in the cross timbers vegetation type of Oklahoma. We examined how cottontail rabbit (Sylvilagus floridanus) density and habitat use were influenced by applications of tebuthiuron or triclopyr, with and without annual burning, on cross timbers rangeland. Line transect flush-counts, mark-recapture livetrapping, and fecal pellet counts were used to evaluate seasonal differences in population density among 5 brush control treatments. Cottontail rabbits $(n=$ 225) were flushed along $362 \mathrm{~km}$ of line transects during 5 census periods. Density in winter was consistently lower than summer for all treatments, except for the untreated control in winter 1987. Line transect density estimates varied from 0 to 1.875 rabbits/ha and suggested that herbicide and annual burning treatments had a positive influence on cottontail rabbit populations compared to untreated controls. Mark-recapture density estimates did not differ among treatments. Fecal pellet counts were greater on herbicide-treated pastures than an untreated control in both spring and fall. Prairie-eastern redcedar (Juniperus virginiana $L_{\text {.) }}$ and forest-prairie ecotone habitats were utilized greater than expected by cottontail rabbits. Mature hardwood overstory and mixedbrush habitats were avoided. Tebuthiuron and triclopyr effectively decreased hardwood overstory and increased preferred habitats for cottontail rabbits.

Key Words: cottontail rabbit, Sylvilagus floridanus, population dynamics, tebuthiuron, triclopyr, brush control, habitat use

The cross timbers land resource area covers nearly 5 million ha of Oklahoma (SCS 1981), and with the remainder of the oakhickory forest of the Ozark Plateaus represents about 19 million ha of land in the central United States (Garrison et al. 1977). Livestock production from these oak-dominated rangelands is relatively low, but appropriate brush management can increase forage and livestock production from these areas (Scifres and Mautz 1978, Stritzke 1980, Scifres et al. 1981). The likelihood of improved cattle production after removal of woody vegetation has promoted increased utilization of herbicides, fire, and mechanical control methods. Continued conversion of oak-dominated rangelands to increase livestock production is anticipated.

Increased interest in wildlife as an additional economic resource (Eltringham 1984) warrants an evaluation of the impacts of any brush management on animal populations. Range improvements that alter vegetation can modify habitat quality for many game species (Beasom and Scifres 1977). In particular, modifications that influence cover or food can change the suitability of a rangeland for wildlife (Borrecco et al. 1974, Darr and Klebenow 1975, Fagerstone et al. 1977, Tanner et al. 1978, Scifres and Koerth 1986).

\footnotetext{
Authors are associate professor, former research assistant, and research assistant, Department of Zoology; unit leader, U.S. Fish and Wildlife Service, Oklahoma Cooperative Fish and Wildlife Research Unit; and professor Department of Agronomy, Oklahoma State University, Stillwater 74078 .

This research was supported by the National Rifle Association of America, Oklahoma Agricultural Experiment Station, National Science Foundation (BSR-8657043), and Oklahoma Cooperative Wildlife and Fisheries Research Unit (U.S. Fish and Wildlife Service, Oklahoma State University. Oklahoma Department of Wildlife Conservation, and Wildlife Management Institute cooperating). This is journal article 5794 of the Oklahoma Agriculture Experiment Station.

Manuscript accepted 10 June 1990.
}

Our objective was to evaluate responses of cottontail rabbit (Sylvilagus floridanus) populations to 4 brush management strategies in the cross timbers of central Oklahoma. We evaluated applications of soil-applied tebuthiuron ( $\mathrm{N}-5-(1,1-$ dimethylethyl)-1,3,4-thiadiazol-2-yl]-N,N'-dimethylurea) and foliage-applied triclopyr ([(3,5,6-trichlor-2-pyridinyl)oxy] acetic acid), in combination with and without prescribed burning, to control overstory hardwoods. Prescribed burning was used as a maintenance treatment to prolong the effective life of the initial herbicide treatment. Responses of cottontail rabbit populations to brush management in the cross timbers are currently unknown.

\section{Methods}

\section{Study Area}

Our study was conducted on the Cross Timbers Experimental Range (CTER), which is located in Payne County $13 \mathrm{~km}$ southwest of Stillwater, Oklahoma. The CTER was established in 1983 to compare vegetation and livestock responses to brush management. This area is located in the western cross timbers forest and occupies a rugged landscape that is dissected by ephemeral and intermittent stream drainages with steep slopes. Soils of the region were described by Gray and Stahnke (1970), and a pre-treatment vegetation inventory of the CTER was completed in 1982 (Ewing et al. 1984).

The dominant vegetation type is upland forest, which is dominated by blackjack (Quercus marilandica Muench.) and post oak (Q. stellata Wangenh.), with tallgrass prairie interspersed on finetextured soils, some of which are naturally revegetating following cropland abandonment (Ewing et al. 1984). The upland forest varies from an open hardwood overstory with productive herbaceous understory to a closed overstory with negligible understory production. Bottomland forest occupies rather restricted positions along drainages. In general, blackjack and post oak composed more than $70 \%$ of the overstory; post oak is about twice as abundant as blackjack oak.

\section{Experimental Design}

The CTER includes twenty 32.4-ha $(0.42 \times 0.83 \mathrm{~km})$ fenced experimental pastures, representing 4 replications of 4 brush management treatments, using combinations of herbicide and annual prescribed burning, and an untreated control (Fig. 1). This provides an experimental design consisting of 4 replications of 5 treatments. The 5 experimental treatments include: (1) tebuthiuron applied aerially at $2.2 \mathrm{~kg} / \mathrm{ha}$ in March 1983; (2) tebuthiuron applied as in treatment \# 1 with prescribed burning in April 1985, 1986, and 1987; (3) triclopyr applied aerially at $2.2 \mathrm{~kg} / \mathrm{ha}$ in June 1983; (4) triclopyr applied as in treatment \#3 with prescribed burning in April 1985, 1986, and 1987; (5) untreated control. Pastures with similar amounts of tallgrass prairie and upland forest habitat were assigned to a replication. All 20 experimental pastures were grazed seasonally by stocker cattle from April through September in 1985, 1986, and 1988, and from mid-March to mid-August in 1987.

\section{Line Transect Counts}

Transects are routinely used for estimating rabbit populations over large areas (Tiemeir 1965, Smith and Nydegger 1985, Wywialowski and Stoddart 1988). We employed a similar technique to estimate cottontail rabbit densities on 2 replications of the 5 brush 


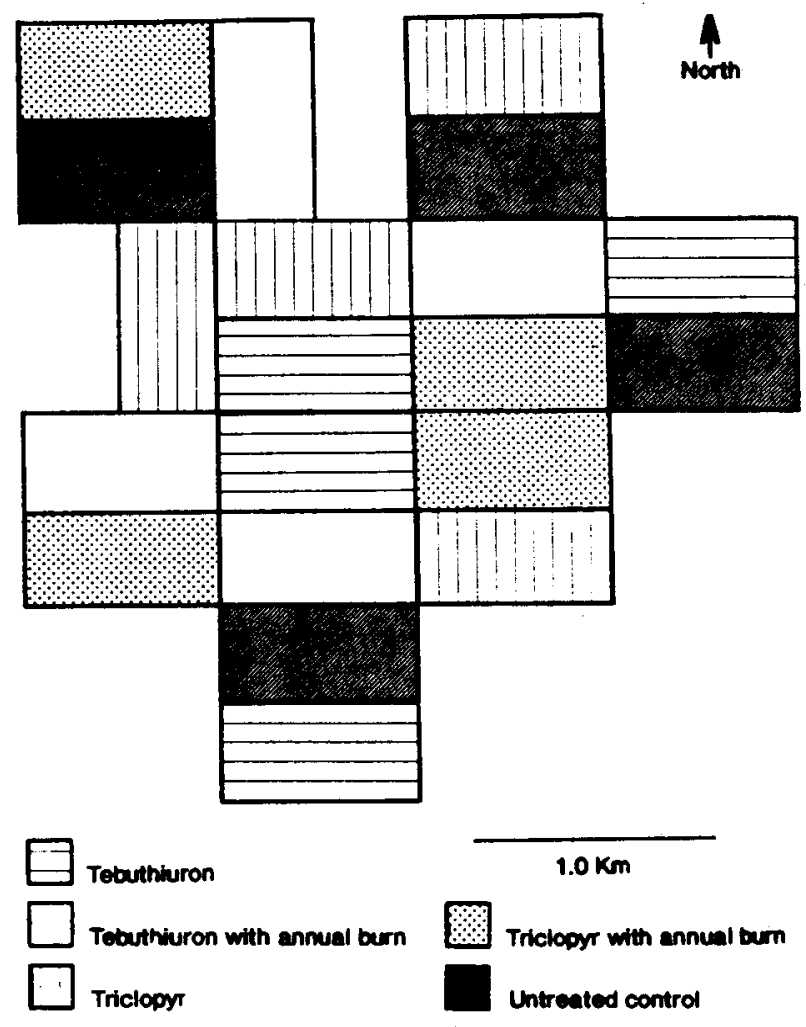

Fig. 1. Map of the Cross Timbers Experimental Range, Payne County, Oklahoma; 20 experimental pastures represented 4 replications of 4 brush management strategles and an untreated contròl. treatments. Three $0.8-\mathrm{km}$ permanent line transects were established on each of 10 pastures. The 3 line transects were spaced systematically and were separated at least $100 \mathrm{~m}$ from boundary fences as well as each other. Each transect was walked 3 times between 0600 and 0900 hours in July (summer) and February (winter) from 1986 to 1988 , which resulted in censusing $14.5 \mathrm{~km}$ on each treatment and $72.5 \mathrm{~km}$ for all treatments within a season. Observers measured the perpendicular distance from the transect line to the point where a cottontail rabbit flushed (Wywialowski and Stoddart 1988). Cottontail rabbit density was estimated for each treatment from the frequency distributions of perpendicular distances using the Fourier Series estimator in program TRANSECT (Burnham et al. 1980).

\section{Mark-Recapture Census}

Density of cottontail rabbit populations is determined in part by availability of adequate nesting and escape cover (Chapman et al. 1982). Therefore, more intensive monitoring with mark-recapture censusing was conducted on 3 adjacent pastures (untreated control, triclopyr only, and a tebuthiuron with fire treatment) that differed substantially in the amount and type of post-treatment cover that was available to cottontail rabbits. Untreated control pastures were characterized by a dense woody canopy with little herbaceous cover and moderate amounts of woody understory; triclopyr-treated pastures contained little overstory with moderate amounts of herbaceous cover and dense understory of herbicideresistant woody species; and, tebuthiuron with fire treatments possessed very little overstory, dense herbaceous cover, and very little woody understory (Engle et al. 1987, Stritzke et al. 1987).

These 3 treated pastures were censused by a mark-recapture technique using single-door box traps $(90 \times 30 \times 30 \mathrm{~cm})$ placed at 75 -m intervals in a $8 \times 4$ grid pattern (32 traps/pasture) that was centered on each pasture. Each trap location on the grid was marked with a permanent wood stake. Traps were baited with

Table 1. Seasonal TRANSECT (Burnham et al. 1980) estimates of cottontall rabbit dendity (rabbits/ha) on 5 brush control treatments on the Cross Timbers Experimental Range, Payne County, Oklahoma; summer 1986 to summer 1988.

\begin{tabular}{|c|c|c|c|c|c|}
\hline Year & Season & Brush treatment & Mean! & $\begin{array}{l}\text { Standard } \\
\text { error }\end{array}$ & $\begin{array}{l}95 \% \text { confidence } \\
\text { interval }\end{array}$ \\
\hline 1986 & Summer & $\begin{array}{l}\text { Tebuthiuron } \\
\text { Tebuthiuron w/fire } \\
\text { Triclopyr } \\
\text { Triclopyr w/fire } \\
\text { Control }\end{array}$ & $\begin{array}{l}0.414^{-} \\
1.404^{\mathrm{b}} \\
1.117^{\mathrm{c}} \\
1.327^{\mathrm{bc}} \\
0.858^{\mathrm{bbc}}\end{array}$ & $\begin{array}{l}0.230 \\
0.340 \\
0.220 \\
0.182 \\
0.354\end{array}$ & $\begin{array}{r}-0.178-1.006 \\
0.521-2.287 \\
0.352-1.882 \\
0.386-2.667 \\
0.015-1.701\end{array}$ \\
\hline 1987 & Winter & $\begin{array}{l}\text { Tebuthiuron } \\
\text { Tebuthiuron w/fire } \\
\text { Triclopyr } \\
\text { Triclopyr w/fire } \\
\text { Control }\end{array}$ & $\begin{array}{l}0.000^{a} \\
0.460^{\mathrm{b}} \\
0.019 \mathrm{~g}^{\mathrm{a}} \\
0.000^{\mathrm{a}} \\
1.875^{\mathrm{c}}\end{array}$ & $\begin{array}{l}0.000 \\
0.230 \\
0.089 \\
0.000 \\
0.718\end{array}$ & $\begin{array}{r}0.000-0.000 \\
-0.132-1.052 \\
-0.213-0.251 \\
0.000-0.000 \\
0.027-3.720\end{array}$ \\
\hline 1987 & Summer & $\begin{array}{l}\text { Tebuthiuron } \\
\text { Tebuthiuron w/fire } \\
\text { Triclopyr } \\
\text { Triclopyr w/fire } \\
\text { Control }\end{array}$ & $\begin{array}{l}0.622^{\mathrm{abc}} \\
0.816^{\mathrm{b}} \\
1.058^{\mathrm{b}} \\
1.606^{\mathrm{b}} \\
0.207^{\mathrm{c}}\end{array}$ & $\begin{array}{l}0.325 \\
0.279 \\
0.269 \\
0.551 \\
0.075\end{array}$ & $\begin{array}{r}-0.215-1.459 \\
0.096-1.535 \\
0.365-1.750 \\
0.188-3.023 \\
0.012-0.402\end{array}$ \\
\hline 1988 & Winter & $\begin{array}{l}\text { Tebuthiuron } \\
\text { Tebuthiuron } w / \text { fire } \\
\text { Triclopyr } \\
\text { Triclopyr w/fire } \\
\text { Control }\end{array}$ & $\begin{array}{l}0.000^{\mathrm{a}} \\
0.061^{\mathrm{b}} \\
0.043^{\mathrm{ab}} \\
0.009^{\mathrm{ab}} \\
0.001^{\mathrm{ab}}\end{array}$ & $\begin{array}{l}0.000 \\
0.027 \\
0.043 \\
0.054 \\
0.163\end{array}$ & $\begin{array}{r}0.000-0.000 \\
-0.009-0.131 \\
-0.068-0.154 \\
-0.112-0.130 \\
-0.301-0.303\end{array}$ \\
\hline 1988 & Summer & $\begin{array}{l}\text { Tebuthiuron } \\
\text { Tebuthiuron } w / \text { fire } \\
\text { Triclopyr } \\
\text { Triclopyr w/fire } \\
\text { Control }\end{array}$ & $\begin{array}{l}0.846^{\mathrm{a}} \\
0.511^{\mathrm{ab}} \\
0.838^{\mathrm{a}} \\
0.471^{\mathrm{ab}} \\
0.062^{\mathrm{b}}\end{array}$ & $\begin{array}{l}0.179 \\
0.244 \\
0.267 \\
0.183 \\
0.014\end{array}$ & $\begin{array}{r}0.385-1.306 \\
-0.117-1.139 \\
0.150-1.525 \\
0.000-0.942 \\
0.026-0.098\end{array}$ \\
\hline
\end{tabular}

${ }^{1}$ Means within a season followed by different letters are significantly different $(P<0.100)$. 
Table 2. Structure characteristics of 5 habitat types on the Cross Timbers Experimental Range, Payne County, Oklahoma (measured in October, 1987).

\begin{tabular}{|c|c|c|c|c|c|c|c|c|c|c|}
\hline \multirow[b]{2}{*}{ Habitat variable } & \multicolumn{2}{|c|}{$\begin{array}{c}\text { Mature hardwood } \\
\text { overstory }\end{array}$} & \multicolumn{2}{|c|}{$\begin{array}{l}\text { Prairie-eastern } \\
\text { redcedar }\end{array}$} & \multicolumn{2}{|c|}{$\begin{array}{c}\text { Forest-prairie } \\
\text { ecotone }\end{array}$} & \multicolumn{2}{|c|}{$\begin{array}{l}\text { Prairie-snag } \\
\text { overstory }\end{array}$} & \multicolumn{2}{|c|}{$\begin{array}{c}\text { Mixed brush-snag } \\
\text { overstory }\end{array}$} \\
\hline & $\overline{\bar{X}}$ & SE & $\bar{X}$ & SE & $\overline{\bar{X}}$ & SE & $\bar{X}$ & $\mathbf{S E}$ & $\overline{\bar{X}}$ & SE \\
\hline $\begin{array}{l}\text { Woody plant density } \\
\text { (stems } / 0.0016 \mathrm{ha})\end{array}$ & 34 & 7 & 2 & 1 & 15 & 6 & 5 & 2 & 24 & 5 \\
\hline $\begin{array}{l}\text { Herbaceous canopy } \\
\text { cover (\%) }\end{array}$ & 10 & 3 & 79 & 3 & 64 & 8 & 78 & 4 & 62 & 5 \\
\hline $\begin{array}{l}\text { Woody understory } \\
\text { canopy cover (\%) }\end{array}$ & 21 & 3 & 6 & 3 & 12 & 7 & 3 & 1 & 24 & 4 \\
\hline $\begin{array}{l}\text { Overstory canopy } \\
\text { cover (\%) } \\
\text { Lateral foliage } \\
\text { density }^{1}\end{array}$ & 61 & 3 & 8 & 3 & 19 & 7 & 18 & 3 & 27 & 5 \\
\hline $\begin{array}{l}0-0.5 \mathrm{~m} \\
0.5-1.0 \mathrm{~m} \\
1.0-1.5 \mathrm{~m} \\
1.5-2.0 \mathrm{~m}\end{array}$ & $\begin{array}{l}3.2 \\
3.4 \\
3.1 \\
3.6\end{array}$ & $\begin{array}{l}0.2 \\
0.1 \\
0.2 \\
0.1\end{array}$ & $\begin{array}{l}2.9 \\
2.4 \\
2.2 \\
2.2\end{array}$ & $\begin{array}{l}0.2 \\
0.3 \\
0.2 \\
0.2\end{array}$ & $\begin{array}{l}3.5 \\
3.4 \\
3.2 \\
3.1\end{array}$ & $\begin{array}{l}0.4 \\
0.4 \\
0.3 \\
0.4\end{array}$ & $\begin{array}{l}3.4 \\
2.6 \\
2.3 \\
2.2\end{array}$ & $\begin{array}{l}0.2 \\
0.2 \\
0.2 \\
0.2\end{array}$ & $\begin{array}{l}3.8 \\
3.4 \\
3.0 \\
3.0\end{array}$ & $\begin{array}{l}0.2 \\
0.2 \\
0.3 \\
0.3\end{array}$ \\
\hline
\end{tabular}

Density classes: $1=0-20 \% ; 2=21-40 \% ; 3=41-60 \% ; 4=61-80 \% ; 5=81-100 \%$

apple and alfalfa and set for 10 consecutive days during late October (fall) and late April (spring) from fall 1986 to fall 1988. Initially, each captured cottontail rabbit was marked with a unique ear tag and released. Recaptures were recorded and released. Mark-recapture data were analyzed using program CAPTURE (Otis et al. 1978) to estimate seasonal abundance for each pasture. We estimated the effective trapping area by adding one-half of the mean maximum recapture distance to the periphery of each grid. Cottontail rabbit density was estimated by dividing the estimated abundance by the effective trapping area (Otis et al. 1978). No cottontail rabbits marked on a pasture were subsequently recaptured on adjacent pastures.

\section{Habitat Use}

Both treated and untreated pastures contain a mosaic of habitat types. We identified 5 post-treatment habitat types on the markrecapture trapping grids: (1) mature hardwood forest, (2) prairie with eastern redcedar, (3) forest-prairie ecotone, (4) prairie with snag overstory, and (5) mixed-brush with snag overstory. Each trap station was assigned to 1 of these habitat types. We measured habitat use by fecal pellet counts (Wolff 1980, Litvaitis et al. 1985) on existing mark-recapture trapping grids. All pellets were counted and removed within a $1-\mathrm{m}$ radius of the trap stake 1 week before each trapping period in October and April from fall 1986 to fall 1988.

Structural characteristics of vegetation were assessed at each pellet plot in early October 1987. Woody plant density in the understory was measured by counting the number of stems with a diameter $<7.5 \mathrm{~cm}$ and a height $>0.5 \mathrm{~m}$ within a $16 \mathrm{~m}^{2}(4 \times 4 \mathrm{~m})$ plot centered on each stake. Canopy cover of herbaceous plants, woody understory plants, and trees was ocularly estimated within each plot. Lateral foliage density, an index of visual obstruction provided by understory vegetation, was measured at $0.5-\mathrm{m}$ intervals from 0 to $2 \mathrm{~m}$ above ground using a vegetation profile board (Nudds 1977) centered on each stake. The observer viewed the board $15 \mathrm{~m}$ from the plot in each of 4 quadrats and a mean value determined for each plot. Measurements were assigned to 1 of 5 density classes based on proportion of the board obstructed from vision (i.e., $1=0-20 \%$ covered, $2=21-40 \%$ covered, etc.).

\section{Statistical Analysis}

Density estimates derived from line-transect and mark-recapture censuses were compared within each season using $Z$ statistics (Brownie et al. 1978, Wywialowski and Stoddart 1988), with significance indicated by $P<0.10$. Pellet counts within a study pasture were grouped by season prior to analysis. To correct for deviations from normality, we performed logarithmic transformations on pellet counts and shrub density counts and arcsin transformations on cover measurements (ground, shrub, canopy) (Sokal and Rohlf 1969). We used chi-square and Bonferroni $Z$ statistics (Neu et al. 1974) to compare availability and use of habitat types. Pairwise correlation coefficients were used to detect vegetation variables that influenced habitat use by cottontail rabbits.

\section{Results and Discussion}

\section{Rabbit Densities}

Cottontail rabbits $(n=225)$ were flushed along $362 \mathrm{~km}$ of line transects during the 5 census periods. Rabbit density in winter was consistently lower than summer for all treatments, except for the untreated control in winter 1987 (Table 1). Although visibility for observing rabbits was excellent on all treatments in winter, no rabbits were counted along transects in several treatments. Density estimates varied from 0 to 1.875 rabbits/ha in winter. Low overwinter survival and dispersal of juveniles (Chapman et al. 1982) probably accounted for most of the seasonal decline in density.

A gradual decline in rabbit density was observed from summer 1986 to summer 1988 on all treatments, except the tebuthiuron treatment, where mean summer densities increased from 0.414 to 0.846 rabbits $/$ ha. The mean estimated density of cottontail rabbits for all treatments declined from 1.024 rabbits/ ha in summer 1986 to 0.545 rabbits/ ha in summer 1988. Decline in rabbit densities during our study could have been due to the periodic cyclic tendencies of this species (Bailey 1968). Although we did not quantify the degree of predation, we frequently noticed predator scats and rabbit kill-sites along transects during 1986 and 1987 . Very few signs of predation were evident in 1988.

Line transect censuses suggested tebuthiuron and triclopyr herbicides and burning can have a positive influence on population density of cottontail rabbits (Table 1). Density was significantly greater on triclopyr than unburned tebuthiuron treatments, and burned tebuthiuron pastures supported a greater density than unburned tebuthiuron pastures, in summer 1986. Densities on treated pastures, except for unburned tebuthiuron, were significantly greater than untreated controls in summer 1987 . Unburned tebuthiuron and triclopyr treatments also supported greater densities than controls in summer 1988.

Although line transect densities were low in winter, treatment differences were evident in both 1987 and 1988 (Table 1). Densities were greater on controls and burned tebuthiuron pastures compared to other brush treatments in winter 1987 and greater on 
burned than unburned tebuthiuron treatments in winter 1988 . No cottontail rabbits were observed on the tebuthiuron treatment in winter 1987 and 1988. We do not think cover availability adequately explained the lack of winter observations on tebuthiuron treatments. Several other treatments also supported few rabbits, despite greater amounts of cover on those treatments.

We captured 164 individual cottontail rabbits on 204 different occasions. The number of cottontail rabbits that were recaptured was not great: only $7.3 \%$ of individuals caught were recaptured within the same season. Large seasonal fluctuations in markrecapture estimates of density were observed (Fig. 2), similar to the

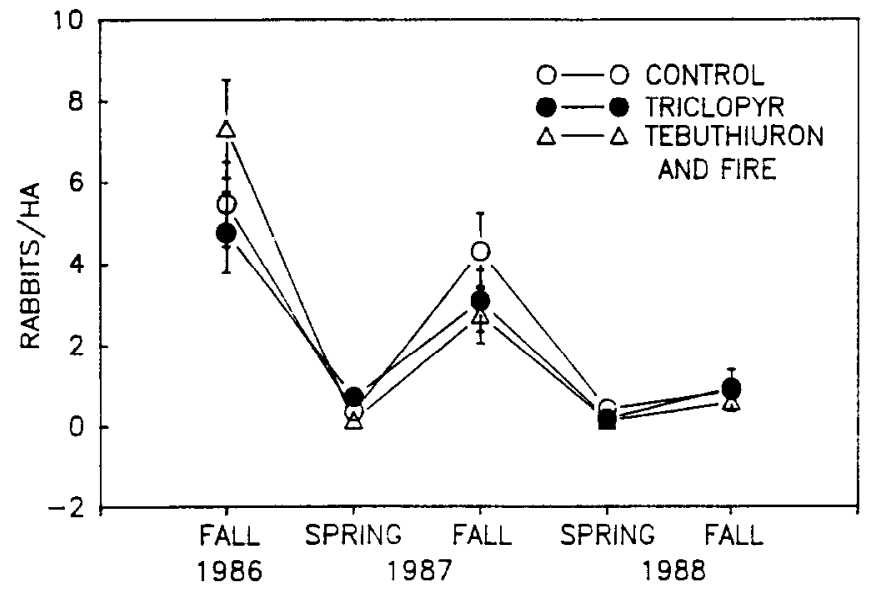

Fic. 2. Estimates of population density (rabbits/ha \pm SE) by markrecapture census of cottontail rabbits in 3 experimental pastures using program CAPTURE (Otis et al. 1978). Populations were sampled in fall and spring from fall 1986 to fall 1988.

fluctuations observed in line transect estimates (Table 1). Markrecapture estimates of density were greatest in fall 1986 with 7.32 rabbits/ha on the tebuthiuron with fire treatment. Fall markrecapture estimates of population density declined during the study and reached their lowest in fall 1988. Mark-recapture estimates for fall 1988 were similar to the estimates derived from line transect censuses, despite the fact that line transect estimates were determined in summer and winter. Fall density estimates should reflect an additional 3 months of recruitment into the population compared to line transect estimates for summer. Spring estimates also could include recruitment into the overwinter population, as the breeding season begins between January and March (Barkalow 1962, Pelton and Provost 1972). This suggested that recruitment was low for all pastures in 1988, possibly in response to lower than normal herbage production which persisted through most of the summer (unpublished data).

Differences in mark-recapture estimates of population density among treatments were not significant $(P>0.10)$ for any fall season because of large standard errors associated with our estimates (Fig. 2). Statistical comparisons among treatments were not performed for spring estimates because no rabbits were recaptured on several treatment pastures. The lack of adequate recaptures during our censuses may have been caused by a large trap-shy component in populations or ineffective baiting techniques.

In contrast to mark-recapture estimates, the seasonal frequency distribution of fecal pellets differed among the 3 trapping grids (Fig. 3). The Bonferroni intervals showed that pastures treated with triclopyr and tebuthiuron with fire were utilized greater than expected $(P<0.05)$ and the control pasture was utilized less than expected $(P<0.05)$ in fall ( 3 sample periods pooled). A similar trend was observed for spring (sample periods pooled) when the tebuthiuron with fire pasture was utilized greater than expected and the control pasture was utilized less than expected. These

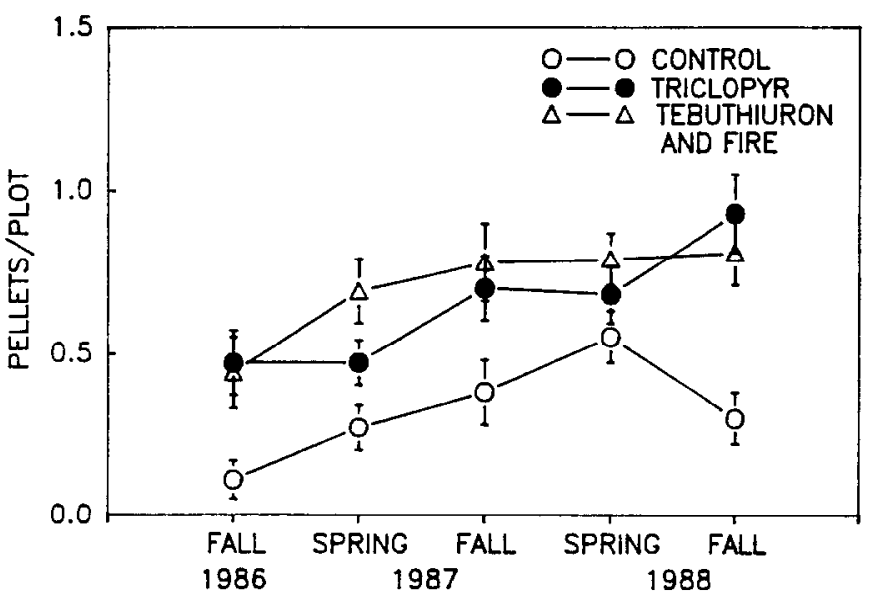

Fig. 3. Fecal pellet density (pellets/plot) on 3 experimental pastures from fall 1986 to fall 1988. Pellet counts were subjected to a $(x+1)$ logarithmic transformation prior to calculating $\bar{x} \pm \mathbf{S E}$.

results agreed more closely with line transect estimates than to mark-recapture results. Our data support the conclusion that brush treatments had a positive influence on cottontail rabbits, but remarkable differences in rabbit density did not exist among treatments. Undoubtedly some of the discrepancy between population indices was a reflection of differences in sensitivity among techniques.

\section{Habitat Use}

The 5 habitat types identified on trapping grids differed markedly in their structural attributes (Table 2). Prairie-eastern redcedar and prairie-snag overstory habitats were characterized by minimal woody understory and overstory canopy, moderate lateral foliage density, and high herbaceous cover. Conversely, mature hardwood and mixed brush-snag overstory habitats had high woody understory cover and lateral foliage density, and low amounts of herbaceous cover. Forest-prairie ecotones occurred less frequently on the grids and represented an intermediate or transitional habitat type. Habitats of mature hardwood overstory or prairies with a snag overstory were the 2 prominent types on our trapping grids (Table 3 ).

Table 3. Total captures of cottontail rabbits in 5 habitat types on the Cross Timbers Experimental Range in fall (1986-88); observed captured totals for each habitat type did not differ $(P>0.10)$ from expected.

\begin{tabular}{lcccc}
\hline \hline & \multicolumn{4}{c}{ Total fall captures } \\
\cline { 2 - 5 } & \multicolumn{4}{c}{ Pro- } \\
portion of \\
Habitat type & $n$ & area & Observed & Expected \\
\hline Mature hardwood overstory & 75 & 0.26 & 42 & 45.2 \\
Prairie-eastern redcedar & 51 & 0.18 & 39 & 31.3 \\
Forest-prairie ecotone & 21 & 0.07 & 13 & 12.2 \\
Prairie-snag overstory & 87 & 0.30 & 58 & 52.2 \\
Mixed brush-snag overstory & 54 & 0.19 & 22 & 33.1 \\
\hline
\end{tabular}

'Represents no. of sample plots $X$ replicates.

Cottontail rabbits are habitat generalists and no universal type appears to be preferred (Chapman et al. 1982). We used live capture and fecal pellet count distributions to assess preferential habitat use on the CTER. Both techniques have been used previously to assess patterns of habitat use by lagomorphs (Adams 1959, Wolff 1980, Litvaitis et al. 1985). Availability of habitat types relative to frequency of live captures of cottontail rabbits (Table 3) showed no preferential utilization of habitats $(P>0.10)$ on the 
Table 4. Cottontall rabbit utilization of 5 habitat types within the Cross Timbers Experimental Range, Payne County, Oklahoma as indicated by the distribution of pellets in fall (1986-88) and spring (1987-88). Observed fecal pellet totals greater (+) or less (-), and no different (NS) than expected for each season are indicated $(P<0.10)$.

\begin{tabular}{|c|c|c|c|c|c|c|c|c|}
\hline \multirow[b]{2}{*}{ Habitat type } & \multicolumn{4}{|c|}{ Fall pellet distribution } & \multicolumn{4}{|c|}{ Spring pellet distribution } \\
\hline & $n^{1}$ & Observed & Expected & Use & $n$ & Observed & Expected & Use \\
\hline $\begin{array}{l}\text { Mature hardwood overstory } \\
\text { Prairie-eastern redcedar } \\
\text { Forest-prairie ecotone } \\
\text { Prairie-snag overstory } \\
\text { Mixed brush-snag overstory }\end{array}$ & $\begin{array}{l}75 \\
51 \\
21 \\
87 \\
54\end{array}$ & $\begin{array}{r}67 \\
1142 \\
644 \\
1007 \\
332\end{array}$ & $\begin{array}{l}830 \\
574 \\
224 \\
958 \\
606\end{array}$ & $\begin{array}{l}- \\
+ \\
+ \\
\text { NS } \\
-\end{array}$ & $\begin{array}{l}50 \\
34 \\
14 \\
58 \\
36\end{array}$ & $\begin{array}{l}183 \\
472 \\
113 \\
364 \\
135\end{array}$ & $\begin{array}{r}329 \\
228 \\
89 \\
380 \\
241\end{array}$ & $\begin{array}{l}- \\
+ \\
+ \\
\text { NS } \\
-\end{array}$ \\
\hline
\end{tabular}

Represents no. of sample plots $X$ replicates.

CTER. In contrast, frequency distributions of fecal pellets showed that prairie-eastern redcedar and forest-prairie ecotone habitats were used more than expected $(P<0.05)$ and habitats with a mature hardwood overstory or mixed brush-snag overstory were used less than expected $(P<0.05)$ (Table 4). Pairwise correlation coefficients (Table 5) suggested that rabbits select for habitats with adequate herbaceous cover and against those with heavy canopy cover. Overstory cover of untreated blackjack and post oak effectively reduced herbaceous cover and thus food availability. Herbicide treatments, particularly tebuthiuron, promoted greater herbaceous cover compared to controls.

Differences between pellet counts and live captures to determine habitat preferences are partially related to the lack of adequate numbers of captures. The basic assumption of both indices is that captures should increase with the amount of time rabbits spend within a habitat type (Litvaitis et al. 1985). In most seasons, we had few recaptures which hindered our ability to detect time spent within a habitat type. Live trapping may have provided different results on habitat use if a large proportion of each population was captured (trap-shy component) or more individuals were recaptured. Live trapping and pellet counts can provide similar information on habitat use (Litvaitis et al. 1985).

\section{Conclusion}

Our objective was to evaluate the impacts of brush management on cottontail rabbit populations in the cross timbers of Oklahoma. Our results indicate that triclopyr and tebuthiuron herbicide applications used in combination with and without prescribed fire (annual) have no adverse impacts on resident populations. Although results were not always consistent, line transect censuses, fecal pellet counts, and habitat preference evaluations suggested that treated areas supported higher densities of cottontail rabbits and provided more preferred habitat types than control areas. Line transect censuses also suggested that prescribed burning had a positive impact on density of cottontail rabbit populations. Habitat preference evaluations indicated that the pasture treated with tebuthiuron provided more fávorable habitat types for cottontail rabbits than the pasture treated with triclopyr.

Successional and climatic changes occurred on treated pastures during the study, and undoubtedly influenced cottontail rabbit numbers and responses to treatments among seasons and years. Herbicide applications were completed in 1983 and prescribed burning was initiated in 1985. Our study began in 1986; we therefore, have no information on population responses immediately following brush control. However, the higher mark-recapture estimates in 1986, followed by a gradual annual decline to 1988 , suggests that populations increased after the first year of treatment.

Applications of tebuthiuron and triclopyr, either with or without prescribed fire, provide a useful management option for increasing the diversity of habitats and increasing preferred habitat types of cottontail rabbits. Our comparisons among 3 pastures suggests that tebuthiuron applications provide more suitable habitat types than applications of triclopyr.

\section{Literature Cited}

Adams, L. 1959. An analysis of a population of snowshoe hares in northwestern Montana. Ecol. Monogr. 29:141-170.

Bailey, J.A. 1968. Regionwide fluctuations in the abundance of cottontails. Trans. North Amer. Wildl. and Nat. Resour. Conf. 33:265-277.

Barkalow, F.S. 1962. Latitude related to reproduction in the cottontail rabbit. J. Wildl. Manage. 26:32-37.

Beasom, S.L., and C.J. Scifres. 1977. Population reactions of selected game species to aerial herbicide applications in south Texas. J. Range Manage. 30:138-142.

Table 5. Pairwise correlation coefficients between cottontail rabbit pellet density or capture frequency and structural characteristics of habitats on the Cross Timbers Experimental Range, Payne County, Oklahoma.

\begin{tabular}{|c|c|c|c|c|c|c|c|c|}
\hline \multirow[b]{2}{*}{$\begin{array}{l}\text { Treatment } \\
\text { pasture }\end{array}$} & \multirow[b]{2}{*}{ Index } & \multirow[b]{2}{*}{$\begin{array}{l}\text { Shrub } \\
\text { density }\end{array}$} & \multicolumn{4}{|c|}{ Habitat variable } & \multirow[b]{2}{*}{ LSF1 $^{2}$} & \multirow[b]{2}{*}{ LDF4 $^{3}$} \\
\hline & & & $\begin{array}{l}\text { Ground } \\
\text { cover }\end{array}$ & $\begin{array}{c}\text { Smilax } \\
\text { cover }\end{array}$ & $\begin{array}{l}\text { Shrub } \\
\text { cover }\end{array}$ & $\begin{array}{l}\text { Canopy } \\
\text { cover }\end{array}$ & & \\
\hline Control & $\begin{array}{l}\text { Pellets/plot } \\
\text { Rabbits/plot }\end{array}$ & $\begin{array}{l}-0.32^{* 4} \\
-0.24\end{array}$ & $\begin{array}{l}0.80^{* * *} \\
0.07\end{array}$ & $\begin{array}{l}-0.14 \\
-0.18\end{array}$ & $\begin{array}{l}-0.41 * * \\
-0.12\end{array}$ & $\begin{array}{l}-0.66^{* * *} \\
-0.07\end{array}$ & $\begin{array}{l}-0.25 \\
-0.14\end{array}$ & $\begin{array}{c}-0.38^{*} \\
0.09\end{array}$ \\
\hline Triclopyr & $\begin{array}{l}\text { Pellets/plot } \\
\text { Rabbits/plot }\end{array}$ & $\begin{array}{l}-0.12 \\
-0.29\end{array}$ & $\begin{array}{l}0.20 \\
0.06\end{array}$ & $\begin{array}{l}-0.03 \\
-0.32\end{array}$ & $\begin{array}{l}-0.29 \\
-0.07\end{array}$ & $\begin{array}{l}-0.53^{* * *} \\
0.02\end{array}$ & $\begin{array}{r}-0.11 \\
0.16\end{array}$ & $\begin{array}{c}-0.34^{*} \\
0.07\end{array}$ \\
\hline $\begin{array}{l}\text { Tebuthiuron } \\
\text { with fire }\end{array}$ & $\begin{array}{l}\text { Pellets/plot } \\
\text { Rabbits/plot }\end{array}$ & $\begin{array}{r}0.02 \\
-0.16\end{array}$ & $\begin{array}{l}0.51^{* * *} \\
-0.01\end{array}$ & $\begin{array}{l}-0.15 \\
-0.35\end{array}$ & $\begin{array}{l}-0.14 \\
-0.22\end{array}$ & $\begin{array}{r}0.06 \\
-0.02\end{array}$ & $\begin{array}{l}-0.19 \\
-0.05\end{array}$ & $\begin{array}{l}0.13 \\
0.23\end{array}$ \\
\hline All treatments & $\begin{array}{l}\text { Pellets/plot } \\
\text { Rabbits/plot }\end{array}$ & $\begin{array}{l}-0.31^{* * *} \\
-0.22^{*}\end{array}$ & $\begin{array}{l}0.68^{* * *} \\
0.04\end{array}$ & $\begin{array}{l}-0.10 \\
-0.26^{* *}\end{array}$ & $\begin{array}{l}-0.41^{* * *} \\
-0.11\end{array}$ & $\begin{array}{l}-0.62^{* * *} \\
0.03\end{array}$ & $\begin{array}{l}-0.08 \\
-0.02\end{array}$ & $\begin{array}{l}-0.36^{* * *} \\
0.10\end{array}$ \\
\hline
\end{tabular}

1 Percent canopy cover attributed a greenbriar (Smilax sp.).

2Lateral foliage density at $0-0.5 \mathrm{~m}$.

${ }^{3}$ Lateral foliage density at $1.5-2.0 \mathrm{~m}$.

$4 P<0.05(*), P<0.01(* *), P<0.001(* * *)$ 
Borrecco, J.E., H.C. Black, and E.F. Hoover. 1974. Response of small mammals to herbicide induced habitat changes. Northwest Sci. 53:97-106.

Brownie, C., D.R. Anderson, K.P. Burnham, and D.S. Robson. 1978. Statistical inference from bond recovery data-a handbook. Resource Pub. 131, U.S. Government Printing Office, Washington, D.C.

Burnham, K.P., D.R. Anderson, and J.L. Laake. 1980. Estimation of density from line transect sampling of biological populations. Wildl. Monogr. 72.

Chapman, J.A., J.G. Hockman, and W.R. Edward. 1982. Cottontail (Sylvilagus floridanus) and allies. p. 83-123. In: J.A. Chapman and G.A. Feldhamer (eds.), Wild mammals of North America: biology, management, economics. John Hopkins Univ. Press, Baltimore.

Darr, G.W., and D.A. Klebenow. 1975. Deer, brush control, and livestock on the Texas Rolling Plains. J. Range Manage. 28:115-119.

Eltringham, S.K. 1984. Wildlife resources and economic development. John Wiley and Sons, New York.

Engle, D.M., J.F. Stritzke, and F.T. McCollum. 1987. Brush management on the Cross Timbers Experimental Range: II. Herbaceous plant responses. Oklahoma Agr. Exp. Sta. Research Report MP-I19.

Ewing, J.H., J.F. Stritzke, and J. Kulbeth. 1984. Vegetation of the Cross Timbers Experimental Range, Payne County, Oklahoma. Oklahoma Agr. Exp. Sta. Res. Rep. P-586.

Fagerstone, K.A., H.P. Tietjen, and G.K. LaVole. 1977. Effects of range treatment with 2,4,-D on prairie dog diet. J. Range Manage. 30:57-60.

Garrison, G.A., A.J. Bjugstad, D.A. Duncan, M.E. Lewis, and D.R. Smith. 1977. Vegetation and environmental features of forest and range ecosystems. Agr. Handb. 475. USDA, U.S. Government Printing Office, Washington, D.C.

Gray, F., and C. Stahnke. 1970. Classification of soils in the savanna-forest transition in eastern Oklahoma. Oklahoma Agr. Exp. Sta. Bull. B-672.

Litvaitis, J.A., J.A. Sherburne, and J.A. Bissonette. 1985. Influence of understory characteristics on snowshow hare habitat use and density. $J$. Wildl. Manage. 49:866-873.

Neu, C.W., C.R. Byers, and J.M. Peek. 1974. A technique for analysis of utilization-availability data. J. Wildl. Manage. 38:541-545.

Vudds, T.D. 1977. Quantifying the vegetative structure of wildlife cover. Wildl. Soc. Bull. 5:113-117.
Otis, D.L., K.P. Bumham, G.C. White, and D.R. Anderson. 1978. Statistical inference from capture data on closed animal populations. Wildl. Monogr. 62.

Pelton, M.R., and E.E. Provost. 1972. Onset of breeding and breeding synchrony by Georgia cottontails. J. Wildl. Manage. 36:544-549.

Scifres, C.J., and J.L. Mautz. 1978. Herbaceous vegetation changes following applications of tebuthiuron for brush control. J. Range Manage. 31:375-378.

Scifres, C.J., and B.H. Koerth. 1986. Habitat alterations in mixed brush from variable rate herbicide patterns. Wildl. Soc. Bull. 14:345-356.

Seifres, C.J., J.W. Stuth, and R.W. Bovey. 1981. Control of oaks (Quercus spp.) and associated woody species on rangeland with tebuthiuron. Weed Sci. 29:270-275.

Smith, G.W., and N.C. Nydegger. 1985. A spotlight, line-transect method for surveying jack rabbits. J. Wildl. Manage. 49:699-702.

Sokal, R.R., and F.J. Rohlf. 1969. Biometry: the principles and practice of statistics in biological research. W.H. Freeman Co., San Francisco, Calif.

Soil Conservation Service. 1981. Land resource regions and major land resource areas of the United States. Agr. Handb. No. 296 USDA, U.S. Government Printing Office, Washington, D.C.

Stritzke, J.F. 1980. Effect of tebuthiuron on herbage production in tallgrass prairies. So. Weed Sci. Proc. 33:114.

Stritzke, J.F., D.M. Engle, and F.T. McCollum. 1987. Brush management on the Cross Timbers Experimental Range. I. Brush problems and responses to herbicides. Oklahoma Agr. Exp. Sta. Res. Rep. MP-119.

Tanner, G.W., J.M. Inglis, and L.H. Blankenship. 1978. Acute impact of herbicide strip treatment on mixed-brush white-tailed deer habitat on the Northern Rio Grande Plain. J. Range Manage. 31:386-391.

Tiemeier, O.W. 1965. The black-tailed jackrabbit in Kansas. Kansas Agr. Exp. Sta. Tech. Bull. 140.

Wolf, J.O. 1980. The role of habitat patchiness in the population dynamics of snowshoe hares. Ecol. Monogr. 50:111-130.

Wywialowski, A.P., and L.C. Stoddart. 1988. Estimation of jack rabbit density: methodology makes a difference. J. Wildl. Manage. 52:57-59.

If a Professional or Soon-to-be-Professional is on a gift list for graduation, promotion, birthday, or holiday giving, consider the gift of a membership in the professional's range society. Write or call Society for Range Management, 1839 York Street, Denver, Colorado 80206. (303) 355-7070. 